Research article

\title{
Optimization of metals extraction from spent lithium-ion batteries by sulphuric acid and sodium metabisulphite through a techno-economic evaluation
}

\author{
Nathália Vieceli $^{\mathrm{a}, *}$, Carlos A. Nogueira ${ }^{\mathrm{b}}$, Manuel F.C. Pereira ${ }^{\mathrm{c}}$, Fernando O. Durão ${ }^{\mathrm{c}}$, \\ Carlos Guimarães ${ }^{c}$, Fernanda Margarido ${ }^{a}$ \\ ${ }^{\text {a }}$ Center for Innovation, Technology and Policy Research - IN+, Instituto Superior Técnico, University of Lisbon, 1049-001, Lisboa, Portugal \\ ${ }^{\mathrm{b}}$ LNEG - Laboratório Nacional de Energia e Geologia, I.P., Campus do Lumiar, 1649-038, Lisboa, Portugal \\ ${ }^{c}$ CERENA - Centro de Recursos Naturais e Ambiente, Instituto Superior Técnico, University of Lisbon, 1049-001, Lisboa, Portugal
}

A R T I C L E I N F O

\section{Keywords:}

Lithium-ion batteries

Economic evaluation

Optimization

Acid leaching

\begin{abstract}
A B S T R A C T
The main factors that affect the extraction of metals from spent lithium-ion batteries by acid leaching using $\mathrm{H}_{2} \mathrm{SO}_{4}$, and sodium metabisulphite, were evaluated and optimized through a set of experiments, framed by a techno-economic approach.

The maximum value of the profit response was obtained with the highest possible values of acid concentration $(2.5 \mathrm{M})$ and time $(2 \mathrm{~h})$, a liquid/solid ratio of $5 \mathrm{~L} / \mathrm{kg}$, and the lowest possible value of temperature $\left(40^{\circ} \mathrm{C}\right)$. After leaching, the electrodes active material contained in the metals decreased, while it was still significant in the graphite, as observed by scanning electron microscopy-energy dispersive spectrometry and x-ray powder diffraction. Even though the performed economic evaluation was a summarized outline it can be considered suitable to compare different leaching conditions and to determine the possible best combinations of factors that can optimize the profit response.
\end{abstract}

\section{Introduction}

Disposed electrical and electronic equipment (WEEE) is one of the fastest growing waste-management problems worldwide. Within the European Union (EU) represents 3-5\% of the total waste produced every year (European Commission, 2017). In 2014, 11.6 Mt of WEEE were generated in Europe, corresponding to $15.6 \mathrm{~kg} /$ inhabitant (Baldé et al., 2015).

The high energy density of lithium-ion batteries (LIBs), associated with other properties, boosted their use on the market of portable electronic devices such as mobile phones, laptops, MP3s and others, as well as in electric vehicles, amounting to billions the number of LIBs units produced every year, thus increasing their wasting (Zeng and Li, 2014; Scrosati and Garche, 2010).

A LIB cell includes two electrodes (positive and negative), a separator, an electrolyte and a steel can. The negative electrode consists of a $\mathrm{Cu}$ foil coated with graphite, while the positive electrode consists of an $\mathrm{Al}$ foil coated with a Li-transition metal mixed oxide, such as $\mathrm{LiCoO}_{2}$, $\mathrm{LiMn}_{2} \mathrm{O}_{4}$, or $\mathrm{LiNiO}_{2}$. Graphite and the mixed oxide are overlaid on the foils using a polymer binder, such as polyvinylidene fluoride (PVDF).
The electrolyte is normally a lithium salt, $\mathrm{LiPF}_{6}, \mathrm{LiBF}_{4}, \mathrm{LiClO}_{4}$, or $\mathrm{LiSO}_{2}$, dissolved in an organic solvent (a mixture of several alkyl carbonates). The separator is made of microporous polypropylene (PP) (Al-Thyabat et al., 2013). Alternative materials for Li-based batteries have been studied and a remarkable recent development is the all-solid-state rechargeable Na or Li battery developed by Braga et al. (2017). This is a noncombustible device with a long life span, fast rates of charge/discharge, and higher energy density than conventional lithium-ion batteries (The University of Texas at Austin and UT News, 2017).

For several years, $\mathrm{LiCoO}_{2}$ has been the most common LIBs active cathode material. Due to some drawbacks such as its high cost and cobalt toxicity, $\mathrm{LiCoO}_{2}$ has been partially replaced by $\mathrm{LiMn}_{2} \mathrm{O}_{4}$ and $\mathrm{Li}$ ( $\mathrm{Mn}, \mathrm{Ni}, \mathrm{Co}) \mathrm{O}_{2}$, particularly in high energy/power applications. As such, active cathode materials in LIBs can contain a variable concentration of $\mathrm{Co}, \mathrm{Ni}$, and $\mathrm{Mn}$, making their recovery more complex (Chen et al., 2011), and more unreliable the attribution of a recycling value (Waste Management World, 2011).

Even though in theory LIBs could be totally recycled with an efficiency rate above $90 \%$ using hydrometallurgical processes, a pyrometallurgical procedure is generally applied, with Li being lost in the

\footnotetext{
* Corresponding author.

E-mail address: nathalia.vieceli@tecnico.ulisboa.pt (N. Vieceli).
} 